\title{
Incorporation of thymidine, adenine and leucine into natural bacterial assemblages
}

\author{
Bo Riemann ${ }^{1}$, Russell T. Bell ${ }^{2}$, Niels O. G. Jørgensen ${ }^{3}$ \\ ${ }^{1}$ The International Agency for ${ }^{14} \mathrm{C}$ Determination, The Water Quality Institute, Agern Alle 11, DK-2970 Hørsholm, Denmark \\ ${ }^{2}$ Institute of Limnology, University of Uppsala, Box 557, S-75122, Uppsala, Sweden \\ ${ }^{3}$ Department of Microbiology, Royal Veterinary \& Agricultural University, Rolighedsvej 21, DK-1958 Frederiksberg C, \\ Denmark
}

\begin{abstract}
Incorporation of ${ }^{3} \mathrm{H}$-thymidine and ${ }^{3} \mathrm{H}$-adenine into DNA and ${ }^{3} \mathrm{H}$-leucine into protein were measured in diluted batch cultures of natural assemblages of coastal marine and freshwater bacteria. Incorporation rates of DNA and protein-synthesis were compared with changes in bacterial DNA and carbon pools. Incorporation rates of all 3 substances peaked before maximum cell densities were reached. ${ }^{3} \mathrm{H}$-leucine incorporation was somewhat higher than both ${ }^{3} \mathrm{H}$-thymidine and ${ }^{3} \mathrm{H}$-adenine incorporation during early exponential and stationary growth periods. The molar ratio of incorporated ${ }^{3} \mathrm{H}$-adenine and ${ }^{3} \mathrm{H}$-thymidine was $1: 1$ in freshwater and 3:1 in seawater cultures, and the cellular DNA content ranged from 2 to $4 \mathrm{fg} \mathrm{cell}^{-1}$, corresponding to an average of $5.5 \%$ of cell carbon. DNA contents predicted from incorporation rates of adenine were 66 to $86 \%$ and of thymidine 28 to $77 \%$ of the measured DNA content. Conversion factors to derive bacterial cell numbers were 0.85 to $1.75 \times 10^{18}$ cells $\mathrm{mol}^{-1}$ thymidine incorporated and 0.47 to $0.92 \times 10^{18}$ cells $\mathrm{mol}^{-1}$ adenine incorporated. Carbon production predicted from incorporation rates of ${ }^{3} \mathrm{H}$-thymidine, ${ }^{3} \mathrm{H}$-adenine or ${ }^{3} \mathrm{H}$-leucine differed by at most $31 \%$ from measured carbon production, suggesting that all 3 methods were applicable to determine growth rates and carbon production in the batch cultures.
\end{abstract}

\section{INTRODUCTION}

The microbial food web is now recognized as an important component of planktonic ecosystems (Williams 1981, Stockner \& Porter 1988). Current interest in this field was stimulated by recent conceptual and methodological developments. For example, field manipulations show that pertubations at the fish level can have effects cascading down to the bacterial level (Riemann 1985). The immediate impetus for this research was the development of new methods for measuring the activity and growth of natural bacterial assemblages (see reviews by van Es \& Meyer-Reil 1982, Karl 1986, Moriarty 1986, Riemann \& Bell 1990). In recent years new methods have been proposed, and the relative merits of earlier methods are often hotly debated (Fuhrman et al. 1986, Karl \& Winn 1986). Despite this, few methodological comparisons have been made under controlled laboratory conditions.

Of the various methods available for the measurement of bacterial growth rates, ${ }^{3} \mathrm{H}$-thymidine incorporation into cold trichloroacetic acid (TCA)-insoluble material (Fuhrman \& Azam 1980, 1982, Riemann et al.
1982, Bell et al. 1983) and leucine incorporation into protein (hot-TCA-insoluble material) have been widely used (Kirchman et al. 1985, Kirchman et al. 1986, ChinLeo \& Kirchman 1988, Simon \& Azam 1989). As an alternative to ${ }^{3} \mathrm{H}$-thymidine, ${ }^{3} \mathrm{H}$-adenine incorporation has been suggested to give an estimate of both stable RNA synthesis (Karl 1979) and DNA synthesis (Karl \& Winn 1986, Bell \& Riemann 1989) for both prokaryotes and unicellular algae (Karl 1981).

When growth rates and carbon production are estimated from thymidine and adenine incorporation rates, several conversion factors are needed (Bjørnsen \& Riemann 1988, Bell \& Riemann 1989): (1) a conversion factor is required to derive cell production from rates of thymidine and adenine incorporation; (2) a mean cell volume is needed to convert cell production to biovolume; and (3) the carbon content must be known to convert biovolume to net carbon production. Although these conversion factors seem to vary between various environments, throughout the season, and to depend on growth conditions and substrate composition, it is nevertheless possible to obtain reliable measurements of growth rates and carbon produc- 
tion of natural bacterial assemblages (Moriarty 1986 Riemann \& Søndergaard 1986, Riemann \& Bell 1990)

${ }^{3} \mathrm{H}$-leucine incorporation has been proposed for the measurement of bacterial protein synthesis and carbon production. Simon \& Azam (1989) demonstrated a significant relationship between rates of protein synthesis and cell volume. Since the protein/dry weight and carbon/dry weight ratios are virtually constant for aquatic bacteria, measurements of protein synthesis for all cell sizes can be converted directly into dry weight or carbon production. As with thymidine, cell production can be derived from leucine incorporation using an empirical conversion factor. However, unlike the case with thymidine, the intracellular and extracellular leucine pools can be measured directly using HPLC. The available evidence indicates that some isotope dilution is always present (factor of 1 to $3 \times$ ), i.e. the de novo synthesis of leucine is apparently never shut off entirely (Simon \& Azam 1989). Concerning thymidine, the thymidine-triphosphate (TTP) in bacterial cells is compartmentalized: a specific TTP pool that participates in DNA synthesis does not mix with the general TTP pool, thus a direct measurement of isotope dilution via HPLC might not be relevant (Moriarty 1986).

It was the objective of this study to compare rates of ${ }^{3} \mathrm{H}$-thymidine, ${ }^{3} \mathrm{H}$-adenine, and ${ }^{3} \mathrm{H}$-leucine incorporation using batch dilution cultures of natural bacterial assemblages and relate these incorporation rates to the actual changes in the carbon and DNA content of the cultures. Only 2 studies have attempted to relate thymidine incorporation rates to the actual increase in DNA (Cho \& Azam 1988, Jeffrey \& Paul 1988) and no study has yet related thymidine incorporation to the actual increase in particulate carbon in dilution culture experiments. This is surprising considering the proliferation of studies deriving empirical conversion factors for deriving cell production from rates of thymidine incorporation (Riemann \& Bell 1990).

\section{MATERIALS AND METHODS}

Water samples were taken dunng April 1989 from a marine station in Øresund at Rungsted Harbour, Denmark, $20 \mathrm{~km}$ north of Copenhagen, and freshwater samples were taken from eutrophic Frederiksborg Slotssø, situated in the centre of the city of Hillerød, Denmark (Andersen \& Jacobsen 1979).

A few hours after sampling, $500 \mathrm{ml}$ portions were filtered through $1.0 \mu \mathrm{m}$ pore-sized filters (Nuclepore Corp., Pleasanton, CA, USA) and mixed with $4.5 \mathrm{l}$ of the same water filtered through a $0.2 \mu \mathrm{m}$ pore-sized filter capsule (12122; Gelman Sciences, Inc., Ann Arbor, MI, USA). Two replicate 51 bottles were made up from each sample station.
Incorporation rates of ${ }^{3} \mathrm{H}$-thymidine, ${ }^{3} \mathrm{H}$-adenine, and ${ }^{3} \mathrm{H}$-leucine were measured 13 times over a $68 \mathrm{~h}$ growth cycle. ${ }^{3} \mathrm{H}$-thymidine incorporation was measured as described by Fuhrman \& Azam (1980) with the following exceptions. Samples of $10 \mathrm{ml}$ were incubated for 30 min with $20 \mathrm{nM}^{3} \mathrm{H}$-thymidine $\left(20 \mu \mathrm{Ci} \mathrm{nmol}{ }^{-1}\right.$; Dupont, NEN Research Products, Boston, MA, USA), Three times during the experimental period, saturation experiments were carried out using replicate samples incubated with 1, 5, 10, 20 and $50 \mathrm{nM}{ }^{3} \mathrm{H}$-thymidine. During all 3 experiments, additions of $>5$ to $10 \mathrm{nM}$ gave maximum labeling of both the freshwater and marine bacteria. Blanks were prepared from samples, with formalin added ( $1 \%$ in final solution) immediately before the addition of ${ }^{3} \mathrm{H}$-thymidine. After incubation, samples were filtered through $0.45 \mu \mathrm{m}$ pore-sized filters (Sartorius; cellulose nitrate, $25 \mathrm{~mm}$ diam.) and washed thoroughly with ice-cold TCA. Filters were dissolved in $1 \mathrm{ml}$ of ethyl acetate, and after $10 \mathrm{~min}$ $10 \mathrm{ml}$ of scintillation cocktail (Filter-count, Packard) was added. Samples were stored $24 \mathrm{~h}$ in the dark at room temperature before they were counted in a scintillation counter (Rack-beta; LKB Instruments, Inc., Rockville, MD, USA). Two samples and one blank were made each sampling.

${ }^{3} \mathrm{H}$-adenine incorporation was carried out according to Bell \& Riemann (1989). Briefly, $5 \mathrm{ml}$ samples were incubated with $55 \mathrm{nM}\left[2{ }^{3} \mathrm{H}\right]$ adenine $\left(15 \mu \mathrm{Ci} \mathrm{nmol}{ }^{-1}\right.$; Dupont) for $2 \mathrm{~h}$. After incubation, the samples were extracted in $0.25 \mathrm{~N} \mathrm{NaOH}$ (final concentration) for 60 min at $60^{\circ} \mathrm{C}$, then acidified with ice-cold $100 \%$ TCA $(1.4 \mathrm{ml}$ per $5 \mathrm{ml}$ of sample) for at least $15 \mathrm{~min}$ and filtered through $0.45 \mu \mathrm{m}$ pore-sized filters (cellulose nitrate; Sartorius). The filters were then treated as described above for ${ }^{3} \mathrm{H}$-thymidine samples. Three samples and 2 blanks ( $1 \%$ in final solution) were made at each sampling.

We assumed that thymidine incorporation into coldTCA-insoluble material (macromolecules) and adenine incorporation into material precipitated after $\mathrm{NaOH}$ hydrolysis (DNA + protein) are in these experiments equivalent to DNA synthesis. This is based on previous experience with bacterioplankton cultures. Riemann et al. (1987) found that thymidine incorporation into DNA was $90 \%$ of total thymidine incorporation into macromolecules in cultures originating from marine coastal areas. Incorporation into DNA is correspondingly high in freshwater cultures (usually $>80 \%$; Bell 1990). Thus, any potential overestimation of DNA synthesis (at most by $25 \%$ ) is counteracted by the corresponding loss of DNA (20 to $30 \%)$ during the extraction procedures (Findlay et al. 1984, Bell \& Ahlgren 1987 Wicks \& Robarts 1987). We measured adenine incorporation into protein (hot-TCA-insoluble material) during stationary phase and found that incorporation into pro- 
tein was 20 to $30 \%$ of total incorporation into DNA + protein. Again, incorporation into DNA can approach $100 \%$ of total incorporation into macromolecules during the exponential growth phase (Bell 1990), thus incorporation into protein was most likely less at that time.

${ }^{3} \mathrm{H}$-leucine incorporation was carried out according to Simon \& Azam (1989) with few exceptions. Samples of $5 \mathrm{ml}$ were incubated with $5 \mathrm{nM}{ }^{3} \mathrm{H}$-leucine $10.5 \mathrm{nM}$ ${ }^{3} \mathrm{H}$-leucine, [specific activity $146 \mu \mathrm{Ci} \mathrm{nmol}{ }^{-1}$; Amersham], $4.5 \mathrm{nM}$ nonradioactive leucine) for $60 \mathrm{~min}$. After incubation, the samples were extracted in $5 \%$ TCA at $95^{\circ} \mathrm{C}$ for $30 \mathrm{~min}$, then cooled on ice and filtered through $0.45 \mu \mathrm{m}$ pore-sized filters (cellulose nitrate; Sartorius). The filters were then treated as described above for ${ }^{3} \mathrm{H}$-thymidine samples. Two samples and one blank were made for each sampling.

The number of bacteria was determined by using the standard acridine orange direct count method (Hobbie et al. 1977). Cell volumes were estimated from measurements of cell dimensions from magnified black and white photographs (Fuhrman 1981, Lee \& Fuhrman 1987). Four pictures were taken of each filter, and a total number of 100 cells were measured from each filter.

Bacterial DNA content was measured according to Paul \& Myers (1982). Volumes of 25 to $50 \mathrm{ml}$ were filtered onto $0.45 \mu \mathrm{m}$ filters (cellulose nitrate; Sartorius), air-dried and stored frozen at $-20^{\circ} \mathrm{C}$ for 1 to $2 \mathrm{~d}$ prior to analysis. The DNA extraction procedure included addition of triton $\mathrm{X}-100$ and SSC $(0.154 \mathrm{M}$ $\mathrm{NaCl}, 0.015 \mathrm{M}$ trisodium citrate, $\mathrm{pH} \mathrm{7.0)}$ and sonification for 15 min using a Sonifier 250 (Branson) at the 30 setting (ca $100 \mathrm{~W}$ ). The efficiency of the sonification procedure was tested on natural bacterial assemblages, and microscopic cell counts revealed that 80 to $90 \%$ of the cells were destroyed after sonification. No attempt was made to correct for the remaining intact cells. Three replicates were made from each experimental bottle from each sampling and blanks were prepared from sonificated filters. After sonification, samples were centrifugated at $10000 \times g$ for $10 \mathrm{~min}$ and $2 \mathrm{ml}$ of the supernatant was taken for assay using Hoechst 33258 (Paul \& Myers 1982)

Particulate carbon was measured after combustion of the particulate material and subsequent quantification of the produced carbon dioxide in an infrared gasanalysator (Analytical Development Co., Hoddesdon, England; 225-MK3). Samples of 25 to $100 \mathrm{ml}$ were filtered through preoxidized glass fiber filters (Whatman $G F / F, 25 \mathrm{~mm}$ in diameter), air-dried and stored frozen for 1 to $2 \mathrm{wk}$ prior to analysis. Two replicate samples were taken from each bottle each sampling. No correction was made for loss of cells that passed through the filters.

\section{RESULTS}

Bacterial abundance increased from an initial cell number of 0.4 to $0.7 \times 10^{6} \mathrm{ml}^{-1}$ to a maximum of $7 \times 10^{6} \mathrm{ml}^{-1}$ in the seawater and $15 \times 10^{6} \mathrm{ml}^{-1}$ in the freshwater cultures (Fig. 1). Mean cell volume decreased slightly during the lag period for the first 3 samplings (the first $13 \mathrm{~h}$ ), then increased significantly from 0.085 to $0.159 \mu^{3}(p<0.05)$ in the freshwater cultures and from 0.110 to $0.209{\mu \mathrm{m}^{3}}^{3}(\mathrm{p}<0.01)$ in the seawater cultures during the experimental period (Table 1). During the last 4 sampling periods, the mean cell volume decreased again (data not shown). There were no significant $(p>0.01)$ differences in the mean cell volume between the freshwater and seawater cultures. Assuming a carbon content of 0.22 to $0.35 \mathrm{pg}$ $\mathrm{um}^{-3}$, the mean cell volume was calculated from cell counts and the measured carbon content (Table 1). The measured mean cell volumes made up on average 71 and $44 \%$ of the calculated mean cell volumes assuming a carbon content of 0.35 or $0.22 \mathrm{pg} \mathrm{mm}^{3}$, respectively

Changes in particulate carbon covaried with changes in particulate DNA (Fig. 2), and DNA constituted on average for the entire material $5.5 \%$ of the carbon content (SE $3.9 \%, \mathrm{n}=40$ ). The DNA content per cell (Fig. 2) ranged from 1.8 to $4.5 \mathrm{fg}$ (mean $=2.8, \mathrm{SD}=0.8$, $\mathrm{n}=50$ ) and was greatest during the exponential growth phase. The correlation between carbon and DNA was not significantly different from $1(\mathrm{p}<0.05$, $\mathrm{n}=38)$ and $\mathrm{r}^{2}$ was 0.83

Generally there was a good correspondence in the trends in incorporation rates shown by the 3 techniques (Fig. 1). ${ }^{3} \mathrm{H}$-leucine incorporation started to increase sooner (after 15 to $30 \mathrm{~h}$ ) than rates of ${ }^{3} \mathrm{H}$-adenine and ${ }^{3} \mathrm{H}$-thymidine incorporation. This was expected since in a 'step-up' situation protein synthesis will increase before DNA synthesis (e.g. Ingraham et al. 1983). Rates of thymidine and adenine incorporation peaked after 37 to $43 \mathrm{~h}$. The correlation between thymidine and adenine incorporation gave $\mathrm{r}^{2}=0.81(\mathrm{p}<0.05, \mathrm{n}=50)$. The correlations between adenine and leucine and thymidine and leucine gave $r^{2}$ values of 0.86 and 0.75 , respectively. We summarized the integrated changes in rates of thymidine and adenine incorporation with the measured conversion factors to calculate cell numbers from incorporation rates and results of predicted and observed increases in the bacterial DNA content (Table 2). Only the first period ( 0 to $45 \mathrm{~h}$ ) was considered for the seawater samples since the increases in cell number, carbon and DNA were small or even negative during the subsequent period. Moles incorporated of adenine and thymidine were almost identical for the freshwater samples, except during the lag period where adenine incorporation was a factor of 2 higher than 

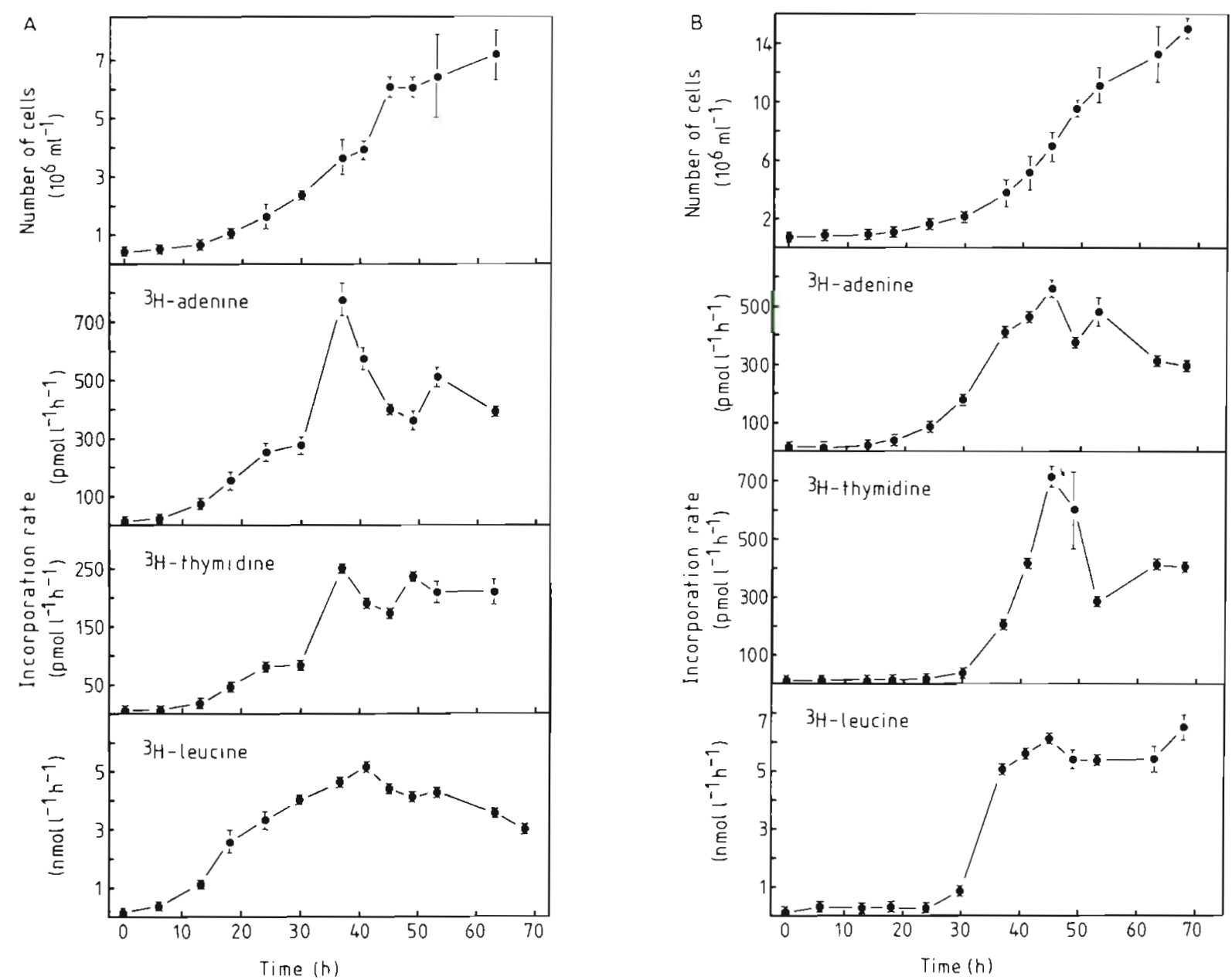

Fig. 1. Changes in bacterial cell number and ${ }^{3} \mathrm{H}$-adenine, ${ }^{3} \mathrm{H}$-thymidine, and ${ }^{3} \mathrm{H}$-leucine incorporation in (A) seawater and (B) freshwater diluted batch cultures. Mean and total variation of 2 replicates are presented

Table 1. Measured and calculated mean cell volumes during different growth phases in the batch cultures. Calculated volumes are based on a carbon content of 0.35 or $0.22 \mathrm{pg} \mathrm{um}^{-3}$ The coefficient of variation did not exceed $8 \%$ of the mean values

\begin{tabular}{|c|c|c|c|c|c|c|}
\hline \multirow{3}{*}{$\begin{array}{l}\text { Sampling } \\
\text { period } \\
\text { (h) }\end{array}$} & \multicolumn{3}{|c|}{ Seawater } & \multicolumn{3}{|c|}{ Freshwater } \\
\hline & \multirow{2}{*}{ Measured } & \multicolumn{2}{|c|}{ Calculated } & \multirow{2}{*}{ Measured } & \multicolumn{2}{|c|}{ Calculated } \\
\hline & & $0.35^{\text {a }}$ & $0.22^{b}$ & & $0.35^{\mathrm{a}}$ & $0.22^{\mathrm{b}}$ \\
\hline $0-13$ & 0.110 & 0.195 & 0.311 & 0.085 & 0.141 & 0.224 \\
\hline $18-45$ & 0.142 & 0.175 & 0.280 & 0.122 & 0.185 & 0.295 \\
\hline $49-68$ & 0.209 & 0.246 & 0.391 & 0.159 & 0.212 & 0.337 \\
\hline \multicolumn{6}{|c|}{${ }^{\mathrm{A}}$ Assuming a carbon content of $0.35 \mathrm{pg} 4 \mathrm{~m}^{-1}$} & \\
\hline
\end{tabular}

thymidine incorporation rates. In the seawater samples, adenine exceeded thymidine incorporation rates by a factor of 3 . The calculated conversion factors ranged from 0.85 to $1.75 \times 10^{18}$ cells mol ${ }^{-1}$ thymidine incorporated and from 0.47 to $0.89 \times 10^{18} \mathrm{cells}^{-1} \mathrm{~mol}^{-1}$ adenine incorporated. The predicted values of DNA ranged between 59 and $86 \%$ of the measured values, except the low (28\%) DNA predicted from thymidine incorporation in the seawater samples (Table 2 ).

In a similar way, a carbon balance was set up between carbon measured and carbon production predicted from rates of ${ }^{3} \mathrm{H}$-thymidine-, ${ }^{3} \mathrm{H}$-adenine-, and 

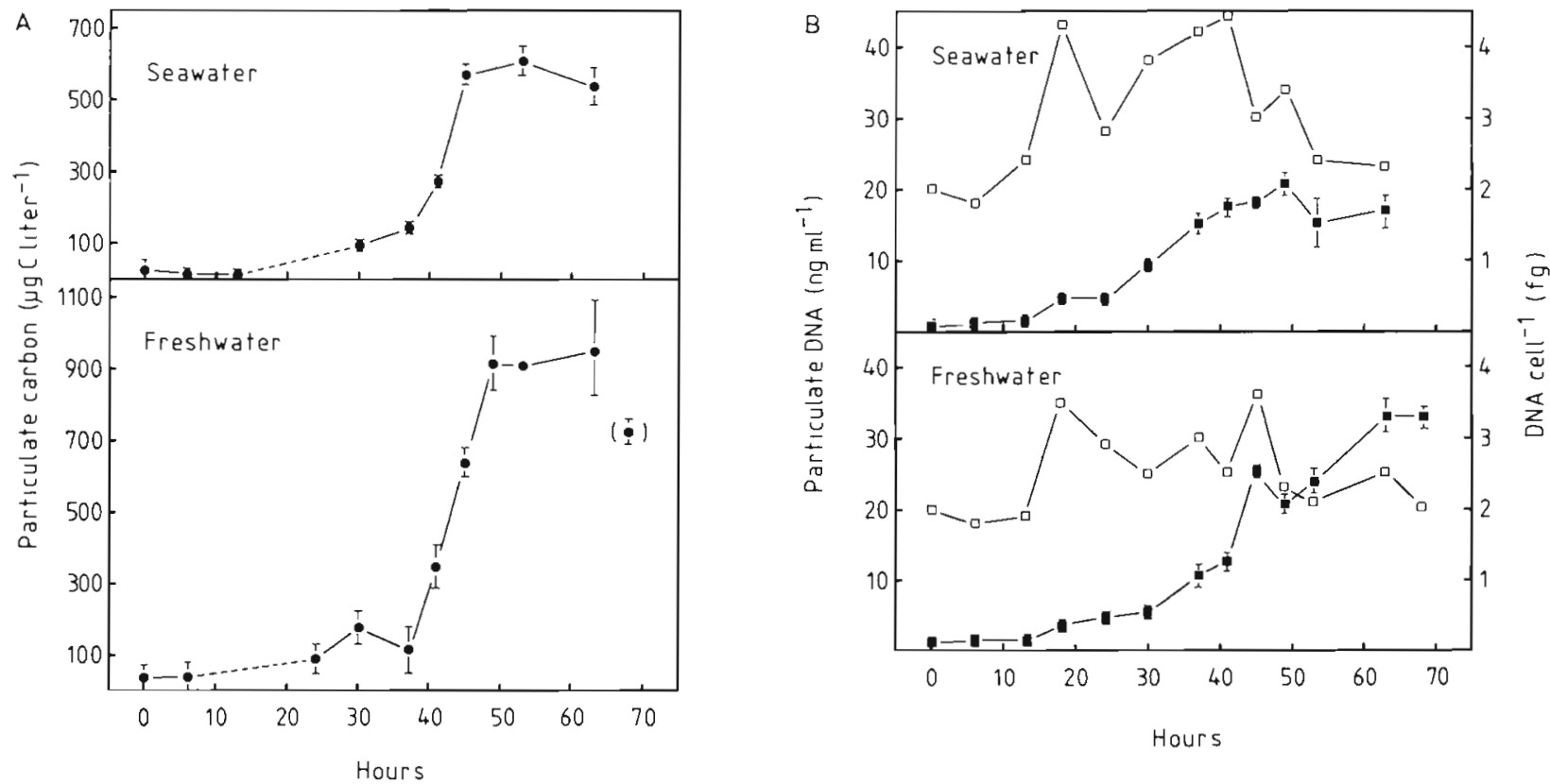

Fig. 2. (A) Particulate carbon and (B) particulate DNA and DNA cell ${ }^{-1}$ in seawater and freshwater batch cultures. Bars indicate total variation of 2 replicate samples. (a) Particulate DNA; (口) DNA cell ${ }^{-1}$

${ }^{3} \mathrm{H}$-leucine-incorporation, the measured conversion factors, and cell volumes, and assuming a carbon con-

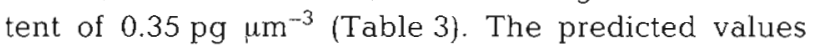
were 8 to $31 \%$ lower than the measured ones in the freshwater samples and 20 to $29 \%$ higher in the seawater samples.

\section{DISCUSSION}

The measured moles of adenine and thymidine incorporated were virtually identical for the freshwater samples (14 nmol thymidine and $16 \mathrm{nmol}$ adenine). This supports the idea that both adenine and thymidine incorporation into DNA can be used to measure DNA synthesis in natural bacterial assemblages (Bell \& Riemann 1989). Overall, for the freshwater samples, the DNA increase predicted from adenine or thymidine incorporation was $68 \%$ of the measured increase. An even better prediction (86\%) was obtained using adenine in the seawater samples. Possible explanations that our predicted DNA increase was at least $25 \%$ less than the measured include: (1) not all bacteria incorpo-

Table 2. ${ }^{3} \mathrm{H}$-thymidine, ${ }^{3} \mathrm{H}$-adenine, and ${ }^{3} \mathrm{H}$-leucine incorporation rates during selected growth periods $(0$ to 68,0 to 49,0 to 41,41 to $68 \mathrm{~h}$ for the freshwater cultures and 0 to $45 \mathrm{~h}$ for the seawater cultures), bacterial increase in cell number, calculated conversion factors, and DNA measured and predicted from incorporation rates of thymidine and adenine

\begin{tabular}{|c|c|c|c|c|c|}
\hline & \multicolumn{4}{|c|}{ Freshwater } & \multirow{2}{*}{$\begin{array}{c}\text { Seawater } \\
0-45\end{array}$} \\
\hline & $0-68$ & $0-49$ & $0-41$ & $41-68$ & \\
\hline Thymidine (nmol $l^{-1}$ ) & 14.2 & 7.4 & 2.5 & 11.7 & 4.0 \\
\hline Adenine $\left(\mathrm{nmol} \mathrm{l}{ }^{-1}\right)$ & 16.0 & 9.1 & 5.2 & 10.8 & 12.1 \\
\hline Leucine $\left(\mathrm{nmol} \mathrm{l}^{-1}\right)$ & 205.2 & 109.9 & 63.8 & 141.7 & 133.5 \\
\hline Bacterial increase $\left(10^{9}\right.$ cells $\left.1^{-1}\right)$ & 14.3 & 8.8 & 4.4 & 9.9 & 5.7 \\
\hline \multicolumn{6}{|c|}{ Conversion factors $\left(10^{18}\right.$ cells $\left.\mathrm{mol}^{-1}\right)$} \\
\hline Thymidine & 1.0 & 1.2 & 1.8 & 0.9 & 1.4 \\
\hline Adenine & 0.9 & 0.9 & 0.8 & 0.9 & 0.5 \\
\hline Leucine & 0.07 & 0.07 & 0.06 & 0.07 & 0.03 \\
\hline DNA measured $\left(\mu \mathrm{g}^{-1}\right)$ & 29.9 & & & 18.8 & 17.4 \\
\hline \multicolumn{6}{|l|}{ DNA predicted: } \\
\hline Thymidine & 17.6 & $(59 \%)^{\mathrm{a}}$ & 14.5 & $(77 \%)^{\mathrm{a}}$ & $(28 \%)^{a}$ \\
\hline Adenine & 19.8 & $(66 \%)^{a}$ & 13.3 & $(71 \%)^{a}$ & $(86 \%)^{a}$ \\
\hline \multicolumn{6}{|l|}{ a Percent of measured } \\
\hline
\end{tabular}


mated from the leucine incorporation. Simon \& Azam (1989) suggested a $10 \mathrm{nM}$ addition; however, according to their Fig. 3a, maximum rates of leucine incorporation were found when more than $2 \mathrm{nM}$ leucine was added. At least in the freshwater samples, additions of 5 and $10 \mathrm{nM}$ concentrations of leucine gave almost identical incorporation rates (Jorgensen unpubl.). Concerning leucine isotope dilution, Simon \& Azam (1989) demonstrated that in 5 out of 6 experiments, intracellular isotope dilution did not exceed a factor of 3 . Obviously, further studies are needed to establish saturation levels of leucine in natural environments and intracellular isotope dilution factors

Carbon production values predicted from rates of incorporation of ${ }^{3} \mathrm{H}$-thymidine, ${ }^{3} \mathrm{H}$-adenine or ${ }^{3} \mathrm{H}$ leucine varied by 8 to $31 \%$ from measured values. A number of methodological precautions have been published on the use of thymidine incorporation to estimate bacterial production (Coveney \& Wetzel 1988, Hollibaugh 1988, Smits \& Riemann 1988, Pedrós-Alió \& Newell 1989, Bell 1990). Chin-Leo \& Kirchman (1988) compared bacterial production from leucine and thymidine incorporation in Chesapeake Bay (USA) and found that results differed by less than $25 \%$, and Bell \& Riemann (1989) reported equivalent estimates of DNA synthesis using adenine and thymidine and batch cultures of freshwater bacteria. Our results support these conclusions.

In summary, the carbon and DNA balances established for our seawater and freswater batch cultures indicate that, with proper precautions, there should be no serious problem in using any of these 3 methods for determining aquatic bacterial production. We found conversion factors ranging between 0.5 and $1.4 \times 10^{18}$ cells $\mathrm{mol}^{-1}$ thymidine and/or adenine incorporated. These are close to the expected 'theoretical' conversion factor (Bell 1988, 1990, Moriarty 1988) and were, in general, confirmed by the actual increases in carbon and DNA. The highest conversion factor we observed $\left(1.4 \times 10^{18}\right.$ cells $\mathrm{mol}^{-1}$ thymidine incorporated in the marine culture) is a 'low factor' considering the entire range of literature values (Riemann \& Bell 1990). Nonetheless, ${ }^{3} \mathrm{H}$-thymidine incorporation only accounted for about $30 \%$ of the overall DNA synthesis. Whether this was due mainly to de novo synthesis or to other factors requires further study. In this context, it seems very likely that even higher conversion factors (> $2 \times 10^{18}$ cells $\mathrm{mol}^{-1}$ ) are unrealistic and indicative of a lack of optimization of experimental protocols.

Acknowledgements. We thank Winnie Martinsen and Mette Petersen for technical assistance. This study was partly supported by the European Commission, MAST, SAFE-project and by the Carlsberg Foundation (J. no. 87-0358/40). Russel Bell received a travel grant from the Danish National Science Research Council (J, no. 41-0003).

\section{LITERATURE CITED}

Andersen, J. M., Jacobsen, O. S. (1979). Production and decomposition of organic matter in eutrophic Frederiksborg Slotsse, Denmark. Arch. Hydrobiol. 85: 511-542

Bell, R. T (1988). Thymidine incorporation and estimates of bacterioplankton production: are the conversion factors valid? Ergebn. Limnol. 31 163-171

Bell, R. T (1990). An explanation for the variability in the conversion factor deriving bacterial cell production from incorporation of ${ }^{3} \mathrm{H}$-thymidine. Limnol. Oceanogr. (in press)

Bell, R. T., Ahlgren, I. (1987). Thymidine incorporation and microbial respiration in the surface sediments of a eutrophic lake. Limnol. Oceanogr. 32: 476-482

Bell, R. T., Ahlgren, G. M., Ahlgren, I. (1983). Estimating bacterioplankton production by measuring ${ }^{3} \mathrm{H}$-thymidine incorporation in an eutrophic Swedish lake. Appl. environ. Microbiol. 45: 1709-1721

Bell, R. T., Riemann, B. (1989). Adenine incorporation into DNA as a measure of microbial production in freshwaters. Limnol. Oceanogr. 34: 435-444

Bjornsen, P. K. (1986). Automatic determinations of bacterioplankton biomass by means of image analyses. Appl. environ. Microbiol. 51: 1199-1204

Bjørnsen, P. K., Riemann, B. (1988). Towards a quantitative stage in the study of microbial processes in pelagic carbon flows. Arch. Hydrobiol. Beih. Ergeb. Limnol. 31 185-193

Bratbak, G., Dundas, I. (1984). Bacterial dry matter content and biomass estimations. Appl. environ. Microbiol. 48: $755-757$

Chin-Leo, G., Kirchman, D. L. (1988). Estimating bacterial production in marine waters from the simultaneous incorporation of thymidine and leucine. Appl. environ. Microbiol. 54: 1394-1399

Cho, C. H., Azam, F. (1988). Heterotrophic bacterioplankton production measurement by the tritiated thymidine incorporation method. Arch. Hydrobiol. Beih. Ergeb. Limnol. 31. $153-162$

Coveney, M. F., Wetzel, R. G. (1988). Experimental evaluation of conversion factors for the $\left({ }^{3} \mathrm{H}\right)$ thymidine incorporation assay of bacterial secondary productivity. Appl, environ. Microbiol. 54: 2018-2026

Douglas, D. J., Novitsky, J. A., Fournier, R. O. (1987). Microautoradiographic-based enumeration of bacteria with estimates of thymidine-specific growth and production rates. Mar Ecol. Prog. Ser. 36: 91-99

Ducklow, H. W. Hill, S. (1985a). The growth of heterotrophic bacteria in the surface waters of warm core rings. Limnol. Oceanogr 30: 239-259

Ducklow, H. W., Hill, S. (1985b). Tritiated thymidine incorporation and the growth of heterotrophic bacteria in warm core rings. Limnol. Oceanogr. 30: 260-272

Fallon, R. D., Newell, S. Y. (1986). Thymidine incorporation by the microbial community of standing dead Spartina alterniflora. Appl. environ. Microbiol. 52: 1206-1208

Findlay, S. E. G., Meyer, J. L., Edwards, R. T (1984). Measuring bacterial production via rate of incorporation of ${ }^{3} \mathrm{H}$ thymidine into DNA. J. microbiol. Meth. 2: 57-72

Fuhrman, J. A. (1981). Influence of method on the apparent size distribution of bacterioplankton cells: epifluorescence microscopy compared to scanning electron microscopy. Mar Ecol. Prog. Ser. 5: 103-106

Fuhrman, J. A., Azam, F. (1980). Bacterioplankton secondary production estimates for coastal waters of British Columbia, Antarctica and California. Appl. environ. Microbiol. 39: $1085-1095$ 
Fuhrman, J. A., Azam, F. (1982). Thymidine incorporation as a measure of heterotrophic bacterioplankton production in marine surface waters: evaluation and field results. Mar. Biol. 66: 109-120

Fuhrman, J. A., Ducklow, H. W., Kirchman, D. L. Hudak, J, McManus, G. B., Kramer, J. (1986). Does adenine incorporation into nucleic acids measure total microbial production? Limnol. Oceanogr. 31: 627-636

Hobbie, J. E., Daley, R. J., Jaspar, S. (1977). Use of nuclepore filters for counting bacteria by fluorescence microscopy Appl environ. Microbiol. 33: 1225-1228

Hollibaugh, J. T (1988). Limitations of the ${ }^{3} \mathrm{H}$-thymidine method for estimating bacterial productivity due to thymidine metabolism. Mar. Ecol. Prog. Ser. 43: 19-30

Ingraham, J. L., Maaløe, O., Neidhardt, F. C. (1983). Growth of the bacterial cell. Sinauer Publ. Inc, Massachusetts

Jeffrey, W. H., Paul, J. H. (1988). Underestimation of DNA synthesis by $\left[{ }^{3} \mathrm{H}\right]$ thymidine incorporation in marine bacteria. Appl environ. Microbiol. 54: 3165-3168

Johnstone, B. H., Jones, R. D. (1989). A study on the lack of [methyl- ${ }^{3} \mathrm{H}$ ]thymidine uptake and incorporation by chemolithotrophic bacteria. Microb. Ecol. 18: 73-77

Karl, D. M. (1979). Measurements of microbial activity and growth in the ocean by rates of stable ribonucleic acid synthesis. Appl. environ. Microbiol. 38: 850-860

Karl, D. M. (1981). Simultaneous rates of RNA and DNA syntheses for estimating growth and cell division of aquatic communities. Appl. environ. Microbiol. 42: 802-860

Karl. D. M. (1986). Determination of in situ microbial biomass, viability, metabolism and growth. In: Pointer, J. S., Leadbeker, E. R. (eds.) Bacteria in nature. Plenum Publ., New York, London, p. 85-176

Karl, D. M., Winn, C. D. (1986). Does adenine incorporation into nucleic acids measure total microbial production? A response to comments by Fuhrman et al. Limnol Oceanogr. 32: 1384-1394

Kirchman, D. L., Knees, E., Hodson, R. E. (1985). Leucine incorporation and its potential as a measure of protein synthesis by bacteria in natural aquatic systems. Appl environ. Microbiol. 49: 599-607

Kirchman, D. L., Newell, S. Y., Hodson, R. E. (1986). Incorporation versus biosynthesis leucine: implications for measuring rates of protein synthesis and biomass production by bacteria in marine systems. Mar Ecol. Prog. Ser 32: $47-59$

Lee, S., Fuhrman, J. A. (1987). Relationships between biovolume and biomass of naturally derived marine bacterioplankton. Appl environ. Microbiol. 53: 1298-1303

Moriarty, D. J. W (1986). Measurements of bacterial growth rates in aquatic systems using rates of nucleic acid synthesis. Adv. Microb. Ecol. 9: 245-292

Monarty, D. J. W. (1988). Accurate conversion factors for calculating bacterial growth rates from thymidine incorpo-

This article was submitted to the editor ration into DNA: elusive or illusive? Ergebn. Limnol. 31. $211-217$

Novitsky, J. A., Morita, R. Y. (1976). Morphological characterization of small cells resulting from nutrient starvation of a psychrophilic marine vibrio. Appl. environ. Microbiol. 36 $506-512$

Paul, J. H., Carlson, D. J. (1984). Genetic material in the marine environment: implications for bacterial DNA. Lim1nol. Oceanogr. 29: 1091-1097

Paul, J. H., Myers, B. (1982). Fluorometric determination of DNA in aquatic microorganisms by use of Hoechst 33258. Appl. environ. Microbiol. 43: 1393-1399

Pedrós-Alió, C. Newell, S. (1989). Microautoradiographic study of thymidine uptake in brackish waters around Sapelo Island, Georgia, USA. Mar. Ecol. Prog. Ser. 55: 83-94

Riemann, B. (1985). Potential importance of fish predation and zooplankton grazing on natural populations of freshwater bacteria. Appl. environ. Microbiol. 50: 187-193

Riemann, B., Bell, R. I (1990). Advances in estimating bacterial biomass and growth in aquatic systems. Arch. Hydrobiol. (in press)

Riemann, B., Bjørnsen, P. K., Newell, S., Fallon, R. (1987). Calculation of cell production of coastal marine bacteria based on measured incorporation of ${ }^{3} \mathrm{H}$-thymidine. Limnol. Oceanogr. 32: 471-476

Riemann, B., Fuhrman, J. A., Azam, F. (1982). Bacterial secondary production in freshwater measured by ${ }^{3} \mathrm{H}$-thymidine incorporation method. Microb. Ecol. 8: 101-114

Riemann, B., Sondergaard, M. (1986). Carbon dynamics in eutrophic, temperate lakes. Elsevier Scientific Publishers, Amsterdam

Rosenbaum-Oliver, D., Zamenhof, S. (1972). Degree of participation of exogenous thymidine in the overall deoxyribonucleic acid synthesis in Escherichia coli. J. Bact. 110: 585-591

Simon, M. Azam, F. (1989). Protein content and protein synthesis rates of planktonic marine bacteria. Mar. Ecol. Prog. Ser 51. 201-213

Smits, J., Riemann, B. (1988). Cell production derived from ${ }^{3} \mathrm{H}-$ thymidine incorporation using freshwater bacteria. Appl. environ. Microbiol. 54: 2213-2219

Stockner, J. G., Porter, K. G. (1988). Microbial food webs in freshwater planktonic ecosystems. In. Carpenter, S. R. (ed.) Complex interactions in lake communities. Springer Verlag, New York, p. 69-83

van Es, F. B., Meyer-Reil, L.-A. (1982). Biomass and metabolism activity of heterotrophic marine bacteria. Adv. microb. Ecol. 6: 111-170

Wicks, R. J., Robarts, R. D. (1987). The extraction and purification of DNA labelled with (methy $1-^{3} \mathrm{H}$ ) thymidine in aquatic bacterial production studies. J. Plankton Res. 9: 1159-1166

Williams, P. J. LeB. (1981). Incorporation of microheterotrophic processes into the classical paradigm of the planktonic food web. Kieler Meeresforsch. Sonderh. 5: 1-28

Manuscript first reccived: March 9, 1990

Revised version accepted: May 10, 1990 